\title{
Chryseobacterium bovis sp. nov., isolated from raw cow's milk
}

\author{
Elionora Hantsis-Zacharov, ${ }^{1}$ Yigal Senderovich ${ }^{1}$ and Malka Halpern ${ }^{1,2}$ \\ ${ }^{1}$ Department of Evolutionary and Environmental Biology, Faculty of Science and Science Education, \\ University of Haifa, Mount Carmel, Haifa 31905, Israel \\ ${ }^{2}$ Department of Biology Education, Faculty of Science and Science Education, University of Haifa, \\ Oranim, Tivon 36006, Israel
}

Correspondence

Malka Halpern

mhalpern@research.haifa.ac.il

\begin{abstract}
Three Gram-negative, rod-shaped, oxidase-positive, aerobic, non-motile bacterial strains, designated $\mathrm{H}^{\top}, \mathrm{H} 10$ and $\mathrm{H} 15$, were isolated during a study on the diversity of culturable psychrotolerant bacteria in raw cow's milk. Comparisons of 16S rRNA gene sequences showed that the three strains were very closely related to each other (sequence similarities of 99.6-99.8\%). A polyphasic taxonomic study of the isolates resulted in their identification as members of the genus Chryseobacterium (family Flavobacteriaceae, phylum Bacteroidetes). The three strains showed $\leqslant 96.9 \%$ sequence similarity with respect to the type strains of described Chryseobacterium species, indicating that $\mathrm{H}^{\top}, \mathrm{H} 10$ and $\mathrm{H} 15$ represent a novel species of the genus Chryseobacterium. The three strains grew at $7-37{ }^{\circ} \mathrm{C}$ (strain $\mathrm{H} 10$ grew at up to $41{ }^{\circ} \mathrm{C}$ ), with $0-2.5 \% \mathrm{NaCl}$ and at $\mathrm{pH} 5.0-9.8$. The dominant cellular fatty acids of strain $\mathrm{H}^{\top}$ were $15: 0$ iso (38.9\%), $15: 0$ anteiso (15.6\%) and $17: 0$ iso $3-\mathrm{OH}(12.7 \%)$. Strain $\mathrm{H} 10$ also possessed $17: 1$ iso $\omega 9 c(14.8 \%)$ as a major fatty acid. On the basis of phenotypic properties and phylogenetic distinctiveness, the three milk isolates represent a novel species in the genus Chryseobacterium, for which the name Chryseobacterium bovis sp. nov. is proposed. The type strain is $\mathrm{H} 9^{\top}$ (=LMG $24227^{\top}=\mathrm{DSM} 19482^{\top}$ ).
\end{abstract}

The genus Chryseobacterium (Vandamme et al., 1994) is a member of the family Flavobacteriaceae (phylum Bacteroidetes) and currently consists of 21 species, with Chryseobacterium gleum as the type species. Two additional species were recently transferred to the novel genus Elizabethkingia (Kim et al., 2005b). Chryseobacterium species inhabit water, soil and the clinical environment (Bernardet et al., 2002, 2005, 2006). They are also a part of the psychrotolerant and proteolytic bacterial population that causes a variety of defects in food products such as milk, meat, poultry and fish (González et al., 2000; Hugo et al., 1999, 2003; de Beer et al., 2005, 2006).

Strains $\mathrm{H}^{9}{ }^{\mathrm{T}}, \mathrm{H} 10$ and $\mathrm{H} 15$ were isolated in the course of a study on the diversity of culturable psychrotolerant bacteria in raw milk. Raw milk from four farms in Israel was sampled every other month from April 2004 to January 2005. The samples were serially diluted and plated on sterile standard plate-count agar (SPC; Oxoid CM0463). Plates were incubated at $7{ }^{\circ} \mathrm{C}$ for 10 days and colonies displaying distinct morphologies were subcultured to

The GenBank/EMBL/DDBJ accession number for the 16S rRNA gene sequence of strain $\mathrm{H}^{\top}$ is EF204446.

An electron micrograph of strain $\mathrm{H}^{\top}$ is available as a supplementary figure with the online version of this paper. obtain pure cultures. Of about 300 pure cultures isolated in this study, strains $\mathrm{H}^{\mathrm{T}}, \mathrm{H} 10$ and $\mathrm{H} 15$ were isolated (at the same farm) on SPC agar during the sampling of April 2004. A comparative analysis of the $16 \mathrm{~S}$ rRNA gene sequences indicated that these strains were members of the genus Chryseobacterium. In order to determine their exact taxonomic positions, they were investigated using a polyphasic taxonomic approach.

Universal bacterial primers 8f and 1512r (based on Escherichia coli positions) were used to amplify internal fragments of the 16S rRNA gene according to Felske et al. (1997). The amplified PCR product (approx. $1.5 \mathrm{~kb}$ ) was purified using a Wizard PCR product purification kit (Promega). Purified PCR products were sequenced (at Technion Medical School, Haifa, Israel) directly by using the dideoxynucleotide chain-termination method with an ABI PRISM 3100 DNA sequencer with BigDye terminator reagents (Applied Biosystems) according to the manufacturer's instructions. Sequencing was performed using primers $8 \mathrm{f}$ ( $5^{\prime}$-GGATCCAGACTTTGATYMTGGCTCAG$\left.3^{\prime}\right)$, 534r (5'-ATTACCGCGGCTGCTGG-3'), 968f (5'AACGCGAAGAACCTTAC- $\left.3^{\prime}\right)$ and 1512f (5'-GTGAAGCTTACGGYTAGCTTGTTACGACTT- $3^{\prime}$ ). The newly determined sequences were compared with those available in GenBank/EMBL (http://www.ebi.ac.uk) by using the wU 
BLAST program (Washington University Basic Local Alignment Search Tool, version 2.0). Sequence alignment was performed using the CLUSTAL $\mathrm{W}$ program; a phylogenetic tree (Fig. 1) was generated using the neighbourjoining method in the MEGA3 software (Kumar et al., 2004).

The three strains shared 99.6-99.8\% $16 \mathrm{~S}$ rRNA gene sequence similarity (Fig. 1). The 1485 bp sequence of strain $\mathrm{H} 9^{\mathrm{T}}$ showed the highest sequence similarity $(96.8 \%)$ to Chryseobacterium hispanicum JCM $13554^{\mathrm{T}}$ and showed $<96.1 \%$ sequence similarity with respect to the type strains of all other Chryseobacterium species (Fig. 1).

For electron microscopy, bacteria grown on SPC agar $\left(48 \mathrm{~h}, 32{ }^{\circ} \mathrm{C}\right)$ were suspended in saline, fixed to a carboncoated grid, stained with $2 \%$ uranyl acetate and then photographed using a JEM-1200EX electron microscope (JEOL). Electron microscopy showed that the cells were non-flagellated rods, $0.5-0.9 \mu \mathrm{m}$ wide and $1.1-2.3 \mu \mathrm{m}$ long (see Supplementary Fig. S1 in IJSEM Online).

For phenotypic characterization, SPC agar was used as the basal growth medium. Salt tolerance was determined at $30{ }^{\circ} \mathrm{C}$ on SPC agar containing $0-5 \%(\mathrm{w} / \mathrm{v}) \mathrm{NaCl}$ (using increments of $0.5 \%$ ). Growth at $4,7,18,22,25,30,32,37$, $40,42,43$ and $45{ }^{\circ} \mathrm{C}$ was measured using SPC agar. The $\mathrm{pH}$ range for growth was determined with SPC adjusted to $\mathrm{pH} 3.5-10.5$ (in increments of $0.5 \mathrm{pH}$ units). The $\mathrm{pH}$ was adjusted prior to sterilization by the addition of $\mathrm{HCl}$ or $\mathrm{NaOH}$ and was measured again after sterilization. Growth under anaerobic conditions was determined after incubation in an anaerobic chamber on SPC agar supplemented with $0.5 \%(\mathrm{w} / \mathrm{v})$ glucose or $0.1 \%(\mathrm{w} / \mathrm{v})$ potassium nitrate. Biochemical tests were performed by using the API 20E, API 20NE, API $50 \mathrm{CH}$ and API ZYM identification systems
(bioMérieux): these tests were carried out according to the manufacturer's instructions except that the incubation temperature was $32{ }^{\circ} \mathrm{C}$. Catalase activity was evidenced by bubble production in a $3 \%(\mathrm{v} / \mathrm{v})$ hydrogen peroxide solution. Oxidase activity was determined using $1 \%$ $N, N, N^{\prime}, N^{\prime}$-tetramethyl- $p$-phenylenediamine dihydrochloride (T3134; Sigma-Aldrich). Growth was tested on MacConkey agar (Difco) and cetrimide agar (Himedia). Haemolytic activity was determined using blood agar base supplemented with $5 \%$ sheep blood (Hylabs). Hydrolysis of casein and tributyrin were determined using $1 \%$ skimmed-milk agar supplemented with $0.5 \%$ yeast extract and tributyrin agar (Hylabs), respectively. Phenotypic traits of the three isolates are given in the species description and in Table 1.

Cell mass for $\mathrm{H}^{\mathrm{T}}, \mathrm{H} 10$ and $\mathrm{H} 15$ was subjected to the $\mathrm{KOH}$ test as described by Fautz \& Reichenbach (1980) and Bernardet et al. (2002). In each case, a very weak colour change was observed, demonstrating that minor amounts of flexirubin-type pigments are produced. The yellow pigments of strain $\mathrm{H}^{\mathrm{T}}$ were extracted and investigated according to Peterson et al. (1954). Briefly, the isolate was grown on Luria-Bertani agar at room temperature under light and dark conditions for $48 \mathrm{~h}$. Cells were transferred to acetone, vortexed for $1 \mathrm{~min}$, allowed to stand for $10 \mathrm{~min}$ and then centrifuged for $3 \mathrm{~min}$ at 13000 r.p.m. Spectral analysis from 400 to $700 \mathrm{~nm}$ was performed on the acetone extract. A broad peak, with two shoulder peaks at 454 and $481 \mathrm{~nm}$ that are typical of carotenoids, was observed (Peterson et al., 1954). Hence, the yellow colour of strain $\mathrm{H}^{\mathrm{T}}$ mostly results from the production of carotenoid-type pigments under light conditions.

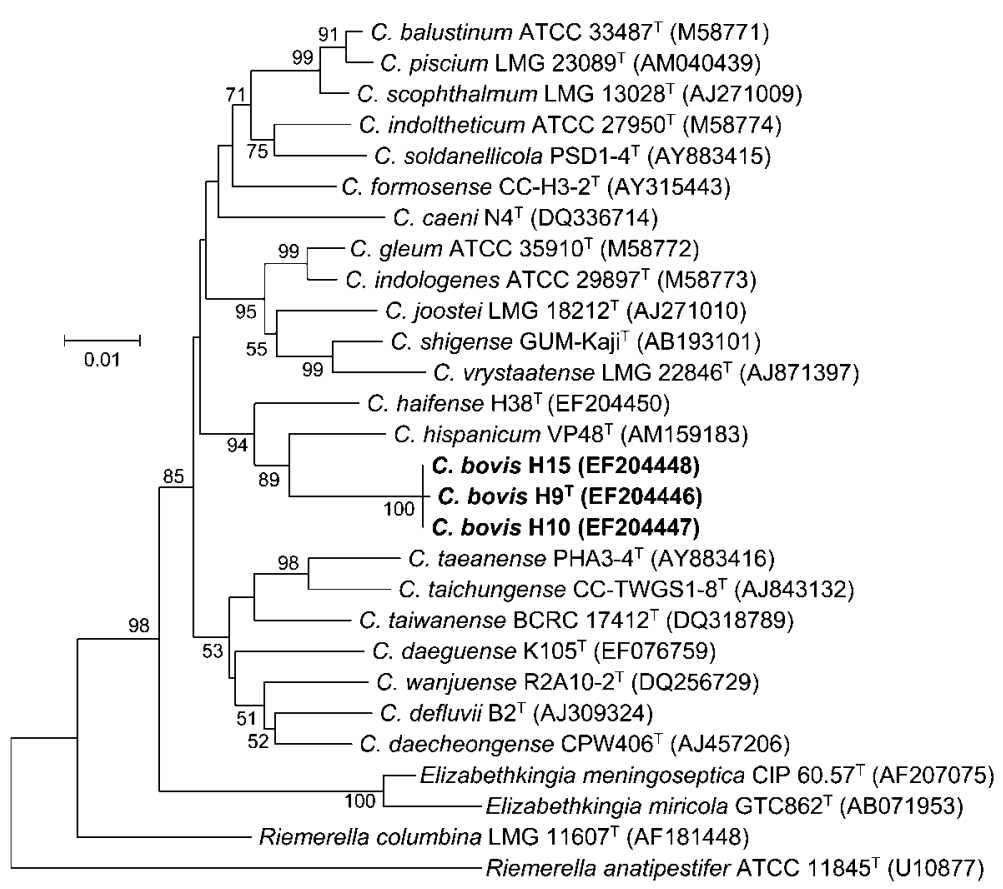

http://ijs.sgmjournals.org
Fig. 1. Neighbour-joining phylogenetic tree, based on 16S rRNA gene sequences, showing the position of strains $\mathrm{H}^{\top}, \mathrm{H} 10$ and $\mathrm{H} 15$, members of the genus Chryseobacterium and representatives of related taxa. Bootstrap percentages $(>50 \%)$ resulting from 1000 replicates are indicated at branching nodes. Bar, 0.01 substitutions per nucleotide position. 
Table 1. Differential characteristics of Chryseobacterium species

Taxa: 1, strains $\mathrm{H}^{\mathrm{T}}$, H10 and H15 (C. bovis sp. nov.); 2, C. haifense LMG 24029 ${ }^{\mathrm{T}}$; 3, C. gleum ( $\left.n=12\right) ; 4$, C. balustinum LMG 8329 ${ }^{\mathrm{T}}$; 5 , C. indologenes $(n=13) ; 6$, C. indoltheticum LMG 4025 $5^{\mathrm{T}} ; 7$, C. scophthalmum $(n=7) ; 8$, C. defluvii DSM 14219 $; 9$, C. joostei $(n=11) ; 10$, C. daecheongense DSM $15235^{\mathrm{T}}$; 11, C. formosense CCUG $49271^{\mathrm{T}} ; 12$, C. taichungense CCUG 50001 ${ }^{\mathrm{T}}$; 13, C. shigense DSM $17126^{\mathrm{T}}$; 14 , C. vrystaatense $(n=36) ; 15$, C. soldanellicola KCTC $12382^{\mathrm{T}} ; 16$, C. taeanense KCTC $12381^{\mathrm{T}} ; 17$, C. piscium $(n=4) ; 18$, C. hispanicum CECT $7129^{\mathrm{T}} ; 19$, C. wanjuense DSM $17724^{\mathrm{T}} ; 20$, C. taiwanense BCRC $17412^{\mathrm{T}} ; 21$, C. caeni DSM $17710^{\mathrm{T}} ; 22$, C. daeguense JCM $14362^{\mathrm{T}}$. The number of strains examined, if greater than one, is shown in parentheses. Data are from Yabuuchi et al. (1983), Holmes et al. (1984), Hugo et al. (2003), Kämpfer et al. (2003), de Beer et al. (2005, 2006), Kim et al. (2005a), Shen et al. (2005), Shimomura et al. (2005), Young et al. (2005), Gallego et al. (2006), Park et al. (2006), Tai et al. (2006), Weon et al. (2006), Quan et al. (2007), Yoon et al. (2007), Hantsis-Zacharov \& Halpern (2007a) and this study. +, Positive; W, weakly positive; -, negative; $\mathrm{V}$, variable; NA, no data available.

\begin{tabular}{|c|c|c|c|c|c|c|c|c|c|c|c|c|c|c|c|c|c|c|c|c|c|c|}
\hline Characteristic & 1 & 2 & 3 & 4 & 5 & 6 & 7 & 8 & 9 & 10 & 11 & 12 & 13 & 14 & 15 & 16 & 17 & 18 & 19 & 20 & 21 & 22 \\
\hline Type of pigment ${ }^{\star}$ & $\mathrm{F}(\mathrm{W})$, & $\mathrm{F}(\mathrm{W})$, & $\mathrm{F}$ & $\mathrm{F}$ & $\mathrm{F}$ & $\mathrm{F}$ & $\mathrm{F}$ & NA & $\mathrm{F}$ & F & $\mathrm{F}$ & F & $\mathrm{F}$ & $\mathrm{F}$ & NA & NA & $\mathrm{F} \quad \mathrm{I}$ & $\mathrm{F}(\mathrm{w})$ & $\mathrm{F}$ & $\mathrm{F}$ & $\mathrm{F}$ & NA \\
\hline & $\mathrm{C} \dagger$ & $\mathrm{C} \dagger$ & & & & & & & & & & & & & & & & & & & & \\
\hline \multicolumn{23}{|l|}{ Growth at/on: } \\
\hline $3 \% \mathrm{NaCl}$ & - & - & NA & $\mathrm{W}$ & + & $\mathrm{W}$ & $\mathrm{W}$ & - & NA & NA & NA & NA & NA & - & + & + & + & - & - & + & + & - \\
\hline Cetrimide agar & - & - & - & - & + & - & - & - & + & NA & NA & NA & $\mathrm{NA}$ & + & NA & NA & - & NA & NA & NA & $\mathrm{NA}$ & NA \\
\hline MacConkey agar & - & - & + & + & + & + & - & - & + & - & - & - & - & - & - & - & - & - & $\mathrm{W}$ & NA & - & - \\
\hline $5{ }^{\circ} \mathrm{C}$ & - & + & - & - & - & + & + & - & + & - & - & - & + & + & + & + & + & + & + & + & + & - \\
\hline $37^{\circ} \mathrm{C}$ & + & + & + & + & + & - & - & + & - & + & + & + & - & - & + & + & - & - & + & + & + & + \\
\hline $42{ }^{\circ} \mathrm{C}$ & - & - & - & - & + & - & - & + & - & - & - & - & - & - & - & - & - & - & - & + & - & - \\
\hline Nitrate reduction & $\mathrm{V} \ddagger$ & - & $\mathrm{NA}$ & + & $\mathrm{V}$ & - & - & - & - & + & - & - & - & - & - & - & + & + & - & - & - & - \\
\hline Urease activity & - & - & $\mathrm{V}$ & - & - & - & + & - & $\mathrm{V}$ & - & - & - & - & + & - & - & + & - & - & - & + & - \\
\hline $\begin{array}{l}\beta \text {-Galactosidase } \\
\text { activity }\end{array}$ & $v \S$ & + & $\mathrm{V}$ & - & - & - & + & NA & - & - & - & $\mathrm{W}$ & NA & $\mathrm{NA}$ & - & - & NA & + & + & - & + & - \\
\hline \multicolumn{23}{|l|}{ Production of: } \\
\hline $\mathrm{H}_{2} \mathrm{~S}$ & - & - & - & - & - & + & - & - & - & - & - & - & - & $\mathrm{V}$ & - & - & - & - & NA & - & - & - \\
\hline Indole & - & + & + & + & + & + & - & + & + & - & + & $\mathrm{W}$ & + & + & - & - & + & $\mathrm{w}$ & NA & + & - & - \\
\hline \multicolumn{23}{|c|}{ Acid production from: } \\
\hline Glucose & $v \S$ & + & + & + & + & NA & - & + & + & - & $\mathrm{W}$ & $\mathrm{W}$ & + & NA & NA & NA & NA & + & + & - & - & + \\
\hline L-Arabinose & - & - & + & NA & $\mathrm{V}$ & - & - & - & - & - & - & - & - & NA & - & - & NA & NA & - & + & - & $\mathrm{w}$ \\
\hline D-Fructose & - & + & + & + & + & - & - & NA & + & + & NA & NA & + & NA & - & - & NA & + & - & $\mathrm{V}$ & - & + \\
\hline Lactose & $v \S$ & + & - & - & - & - & - & NA & - & - & NA & - & - & $\mathrm{NA}$ & - & - & NA & - & - & - & - & + \\
\hline Maltose & $v \S$ & + & + & - & + & + & - & + & + & - & - & + & - & NA & - & - & NA & + & - & - & - & + \\
\hline D-Mannitol & - & - & - & - & $\mathrm{V}$ & NA & - & - & $\mathrm{V}$ & - & - & - & - & NA & - & - & NA & - & - & - & - & - \\
\hline Trehalose & - & - & + & - & + & - & - & + & + & + & + & + & - & NA & - & - & NA & - & + & - & - & + \\
\hline D-Xylose & - & - & $\mathrm{V}$ & - & - & - & - & - & - & + & w & + & - & $\mathrm{NA}$ & - & - & $\mathrm{NA}$ & + & - & $\mathrm{NA}$ & - & w \\
\hline $\begin{array}{l}\text { DNA G + C content } \\
(\mathrm{mol} \%)\end{array}$ & 38.6 & 37.8 & 37.6 & 33.1 & 38.5 & 33.8 & 34.2 & 38.8 & 36.8 & 36.6 & $\mathrm{NA}$ & $\mathrm{NA}$ & 36.6 & 37.1 & 28.8 & 32.1 & 33.6 & 34.3 & 37.8 & 36.8 & 38.2 & 36.8 \\
\hline
\end{tabular}

${ }^{*} \mathrm{C}$, Carotenoid-type; F, flexirubin-type.

$\dagger$ Yellow pigments are produced only when bacteria are grown under light conditions.

$\ddagger$ Strains $\mathrm{H} 9^{\mathrm{T}}$ and $\mathrm{H} 15$ reduce nitrate to nitrite; strain $\mathrm{H} 10$ reduces nitrate to $\mathrm{N}_{2}$.

$\S$ Strains $\mathrm{H} 9^{\mathrm{T}}$ and $\mathrm{H} 15$ are positive; strain $\mathrm{H} 10$ is negative.

For cellular fatty acid analysis, the three strains were cultured on tryptic soy agar (Difco) for $24 \mathrm{~h}$ at $28{ }^{\circ} \mathrm{C}$ and the fatty acids extracted and methylated (Ben-Ze'ev et al., 2005). The fatty acid methyl esters were analysed by gas chromatography using the MIDI/Hewlett Packard microbial identification system (Analytical Services). The major fatty acids $(>10 \%)$ of strain $\mathrm{H}^{\mathrm{T}}$ were $15: 0$ iso, 15:0 anteiso and 17:0 iso 3-OH. Strains $\mathrm{H} 10$ and $\mathrm{H} 15$ possessed the same major fatty acids except that strain $\mathrm{H} 10$ also possessed 17:1 iso $\omega 9 c$ as a major fatty acid.
For determination of the DNA $\mathrm{G}+\mathrm{C}$ content, genomic DNA of strain $\mathrm{H} 9^{\mathrm{T}}$ was prepared according to a modification of the procedure of Wilson (1987). The DNA $\mathrm{G}+\mathrm{C}$ content (mol\%) was determined using HPLC analysis of hydrolysed DNA according to Mesbah et al. (1989). The analysis was performed by the BCCM/LMG Bacteria Collection Identification Service (Laboratory of Microbiology, Ghent University, Ghent, Belgium). The DNA $\mathrm{G}+\mathrm{C}$ content of strain $\mathrm{H9}^{\mathrm{T}}$ was $38.6 \mathrm{~mol} \%$. 
Strains $\mathrm{H}^{\mathrm{T}}, \mathrm{H} 10$ and $\mathrm{H} 15$ were isolated when psychrotolerant bacterial communities in raw milk, and their proteolytic and lipolytic traits, were studied (HantsisZacharov \& Halpern, 2007b); $5 \%$ of the isolates were members of the genus Chryseobacterium (GenBank accession numbers EF204446-EF204459). The three strains exhibited lipolytic activity, and strains $\mathrm{H} 9^{\mathrm{T}}$ and $\mathrm{H} 15$ also showed proteolytic activity. Heat-stable proteolytic and lipolytic enzymes originating from psychrotolerant bacteria are a limiting factor in the maintenance of the flavour quality of fluid milk and its products. However, the impact of chryseobacterial isolates and, in particular, strains $\mathrm{H}^{\mathrm{T}}$, $\mathrm{H} 10$ and $\mathrm{H} 15$ on milk quality remains to be determined.

The main characteristics of the novel isolates are the same as those of the known Chryseobacterium strains, i.e. they are non-motile rods, they are catalase- and oxidase-positive, they contain flexirubin-type pigments and they contain 15:0 iso and 17:0 iso $3-\mathrm{OH}$ as the predominant fatty acids. However, the novel isolates differed from the described Chryseobacterium species in terms of some phenotypic traits (listed in Table 1) and in having large amounts of the fatty acid 15:0 anteiso (16.6\%) (Bernardet et al., 2006). In addition to containing small amounts of flexirubin-type pigments, the three isolates produced carotenoid-type pigments when grown under light conditions. While flexirubin-type pigments have been found in all Chryseobacterium species described to date, the presence of carotenoid-type pigments has not been investigated in these species. Although basically aerobic, the isolates were also able to grow under anaerobic conditions when nitrate was provided, as already reported for some C. gleum and Chryseobacterium indologenes strains (Holmes et al., 1984; Bernardet et al., 2006).

On the basis of the data from our phenotypic and phylogenetic analysis of the three milk isolates, strains $\mathrm{H} 9^{\mathrm{T}}$, H10 and H15 represent a novel species of the genus Chryseobacterium, for which the name Chryseobacterium bovis sp. nov. is proposed.

\section{Description of Chryseobacterium bovis sp. nov.}

Chryseobacterium bovis (bo'vis. L. gen. n. bovis of a cow, referring to the isolation from raw cow's milk).

Cells are Gram-negative, non-motile rods, $0.5-0.9 \mu \mathrm{m}$ wide and 1.1-2.3 $\mu \mathrm{m}$ long. After $48 \mathrm{~h}$ incubation on sterile SPC agar at $30{ }^{\circ} \mathrm{C}$ in the dark, colonies are circular with entire edges, opaque, smooth and cream-coloured. When light is provided during growth, colonies are yellow-coloured because of the production of carotenoid-type pigments (absorbance peaks at 454 and $481 \mathrm{~nm}$ ). Weakly positive in the $\mathrm{KOH}$ test, indicating the presence of small amounts of flexirubin-type pigments. Good growth occurs under aerobic conditions. Growth is also observed after 5 days under anaerobic conditions on SPC agar containing $0.1 \%$ $(\mathrm{w} / \mathrm{v})$ potassium nitrate, but not on SPC agar with $0.5 \%$ glucose. Grows at $7-37{ }^{\circ} \mathrm{C}$ (strain $\mathrm{H} 10$ grows at temperatures up to $41{ }^{\circ} \mathrm{C}$ ) (optimum, $30-32{ }^{\circ} \mathrm{C}$ ), with $0-2.5 \%$
$\mathrm{NaCl}$ (optimum, 0-1.75\% $\mathrm{NaCl}$ ) and at $\mathrm{pH} 5.0-9.8$ (optimum, pH 6.5-8.5). Good growth occurs on SPC and tryptic soy agars, but not on MacConkey or cetrimide agar. No haemolysis occurs on 5\% sheep-blood agar. Catalase and oxidase activities are present. Casein (except for strain H10) and tributyrin are hydrolysed. In API 20NE tests after $48 \mathrm{~h}$ incubation at $32{ }^{\circ} \mathrm{C}$, all three strains hydrolyse aesculin and assimilate glucose, mannose and maltose, but only $\mathrm{H}^{\mathrm{T}}$ and $\mathrm{H} 15$ assimilate arabinose, mannitol, $\mathrm{N}$-acetylglucosamine, gluconate and adipic and malic acids. The following results are obtained from API $20 \mathrm{E}$ strips after $24 \mathrm{~h}$ incubation at $32{ }^{\circ} \mathrm{C}$ : acetoin is produced; $\beta$-galactosidase activity is present (except for strain H10); gelatin is hydrolysed (except for strain H10); $\mathrm{H}_{2} \mathrm{~S}$ and indole are not produced; urea is not hydrolysed; citrate is not utilized; and arginine dihydrolase, lysine and ornithine decarboxylases and tryptophan deaminase activities are absent. In API $50 \mathrm{CH}$ strips incubated for $48 \mathrm{~h}$ at $32{ }^{\circ} \mathrm{C}$, acid is produced from D-glucose, maltose, D-lactose and D-mannose (except for strain H10). In API ZYM strips incubated for $4.5 \mathrm{~h}$, alkaline and acid phosphatases, esterase (C4), esterase lipase (C8), leucine arylamidase, valine arylamidase, naphthol-AS-BI-phosphohydrolase and $\alpha$-glucosidase activities are present in all the three strains. Cystine arylamidase and $\beta$-galactosidase activities are present in strains $\mathrm{H} 9^{\mathrm{T}}$ and $\mathrm{H} 15$ and trypsin activity is present only in strain H10. The predominant cellular fatty acids of the type strain are 15:0 iso (38.9\%), 15:0 anteiso $(15.6 \%)$ and $17: 0$ iso $3-\mathrm{OH}(12.7 \%)$. The following fatty acids are present as minor components: summed feature 3 (comprising 15:0 iso $2-\mathrm{OH}$ and/or $16: 1 \omega 7 c ; 8.7 \%$ ), $13: 0$ iso $(4.8 \%), 16: 03-\mathrm{OH}(3.9 \%), 15: 0$ iso $3-\mathrm{OH}(2.6 \%)$, $17: 1$ iso $\omega 9 c(2.5 \%), 16: 0(2.1 \%)$, unknown 16.582 $(1.7 \%), 16: 0$ iso $3-\mathrm{OH}(1.6 \%)$ and $17: 0-2-\mathrm{OH}(1.3 \%)$. Traces $(<1 \%)$ of $13: 0$ anteiso, $14: 0,14: 0$ iso, $15: 0,15: 0$ $2-\mathrm{OH}$ and $18: 1 \omega 5 c$ are also present. In strain $\mathrm{H} 10,17: 1$ iso $\omega 9 c$ is also a major fatty acid $(14.8 \%)$. The DNA G $+\mathrm{C}$ content of the type strain is $38.6 \mathrm{~mol} \%$.

The type strain, $\mathrm{H}^{\mathrm{T}}\left(=\mathrm{LMG} 24227^{\mathrm{T}}=\mathrm{DSM} 19482^{\mathrm{T}}\right)$, was isolated from raw milk in Israel. Strains H15 (=LMG $24229=$ DSM 19481) and H10 (=LMG $24228=$ DSM 19483) are reference strains.

\section{Acknowledgements}

This work was supported by a grant from the Tnuva Research Institute, Israel.

\section{References}

Ben-Ze'ev, I. S., Levy, E., Eilam, T. \& Anikster, Y. (2005). Whole-cell fatty acid profiles - a tool for species and subspecies classification in the Puccinia recondita complex. J Plant Pathol 87, 187-197.

Bernardet, J.-F., Nakagawa, Y. \& Holmes, B. (2002). Proposed minimal standards for describing new taxa of the family Flavobacteriaceae and emended description of the family. Int J Syst Evol Microbiol 52, 1049-1070. 
Bernardet, J. F., Vancanneyt, M., Matte-Tailliez, O., Grisez, L., Tailliez, P., Bizet, C., Nowakowski, M., Kerouault, B. \& Swings, J. (2005). Polyphasic study of Chryseobacterium strains isolated from diseased aquatic animals. Syst Appl Microbiol 28, 640-660.

Bernardet, J.-F., Hugo, C. \& Bruun, B. (2006). The genera Chryseobacterium and Elizabethkingia. In The Prokaryotes: a Handbook on the Biology of Bacteria, 3rd edn, vol. 7, pp. 638-676. Edited by M. Dworkin, S. Falkow, E. Rosenberg, K. H. Schleifer \& E. Stackebrandt. New York: Springer.

de Beer, H., Hugo, C. J., Jooste, P. J., Willems, A., Vancanneyt, M., Coenye, T. \& Vandamme, P. A. R. (2005). Chryseobacterium vrystaatense sp. nov., isolated from raw chicken in a chicken processing plant. Int J Syst Evol Microbiol 55, 2149-2153.

de Beer, H., Hugo, C. J., Jooste, P. J., Vancanneyt, M., Coenye, T. \& Vandamme, P. (2006). Chryseobacterium piscium sp. nov., isolated from fish of the South Atlantic Ocean off South Africa. Int J Syst Evol Microbiol 56, 1317-1322.

Fautz, E. \& Reichenbach, H. (1980). A simple test for flexirubin-type pigments. FEMS Microbiol Lett 8, 87-91.

Felske, A., Rheims, H., Wolterink, A., Stackebrandt, E. \& Akkermans, A. D. (1997). Ribosome analysis reveals prominent activity of an uncultured member of the class Actinobacteria in grassland soils. Microbiology 143, 2983-2989.

Gallego, V., Garcia, M. T. \& Ventosa, A. (2006). Chryseobacterium hispanicum sp. nov., isolated from the drinking water distribution system of Sevilla, Spain. Int J Syst Evol Microbiol 56, 1589-1592.

González, C. J., Santos, J. A., Garcia-Lopez, M. L. \& Otero, A. (2000). Psychrobacters and related bacteria in freshwater fish. J Food Prot 63, 315-321.

Hantsis-Zacharov, E. \& Halpern, M. (2007a). Chryseobacterium haifense sp. nov., a psychrotolerant bacterium isolated from raw milk. Int J Syst Evol Microbiol 57, 2344-2348.

Hantsis-Zacharov, E. \& Halpern, M. (2007b). Culturable psychrotrophic bacterial communities in raw milk and their proteolytic and lipolytic traits. Appl Environ Microbiol 73, 7162-7168.

Holmes, B., Owen, R. J., Steigerwalt, A. G. \& Brenner, D. J. (1984). Flavobacterium gleum, a new species found in human clinical specimens. Int J Syst Bacteriol 34, 21-25.

Hugo, C. J., Jooste, P. J., Segers, P., Vancanneyt, M. \& Kersters, K. (1999). A polyphasic taxonomic study of Chryseobacterium strains isolated from dairy sources. Syst Appl Microbiol 22, 586-595.

Hugo, C. J., Segers, P., Hoste, B., Vancanneyt, M. \& Kersters, K. (2003). Chryseobacterium joostei sp. nov., isolated from the dairy environment. Int J Syst Evol Microbiol 53, 771-777.

Kämpfer, P., Dreyer, U., Neef, A., Dott, W. \& Busse, H.-J. (2003). Chryseobacterium defluvii sp. nov., isolated from wastewater. Int J Syst Evol Microbiol 53, 93-97.

Kim, K. K., Bae, H.-S., Schumann, P. \& Lee, S.-T. (2005a). Chryseobacterium daecheongense sp. nov., isolated from freshwater lake sediment. Int J Syst Evol Microbiol 55, 133-138.

Kim, K. K., Kim, M. K., Lim, J. H., Park, H. Y. \& Lee, S. T. (2005b). Transfer of Chryseobacterium meningosepticum and Chryseobacterium miricola to Elizabethkingia gen. nov. as Elizabethkingia meningoseptica comb. nov. and Elizabethkingia miricola comb. nov. Int J Syst Evol Microbiol 55, 1287-1293.

Kumar, S., Tamura, K. \& Nei, M. (2004). MEGA3: integrated software for molecular evolutionary genetics analysis and sequence alignment. Brief Bioinform 5, 150-163.

Mesbah, M., Premachandran, U. \& Whitman, W. B. (1989). Precise measurement of the $\mathrm{G}+\mathrm{C}$ content of deoxyribonucleic acid by highperformance liquid chromatography. Int J Syst Bacteriol 39, 159-167.

Park, M. S., Jung, S. R., Lee, K. H., Lee, M. S., Do, J. O., Kim, S. B. \& Bae, K. S. (2006). Chryseobacterium soldanellicola sp. nov. and Chryseobacterium taeanense sp. nov., isolated from roots of sand-dune plants. Int J Syst Evol Microbiol 56, 433-438.

Peterson, W. J., Bell, T. A., Etchells, J. L. \& Smart, W. W. G., Jr (1954). A procedure for demonstrating the presence of carotenoid pigments in yeasts. J Bacteriol 67, 708-713.

Quan, Z. X., Kim, K. K., Kim, M. K., Jin, L. \& Lee, S. T. (2007). Chryseobacterium caeni sp. nov., isolated from bioreactor sludge. Int $J$ Syst Evol Microbiol 57, 141-145.

Shen, F.-T., Kämpfer, P., Young, C.-C., Lai, W.-A. \& Arun, A. B. (2005). Chryseobacterium taichungense sp. nov., isolated from contaminated soil. Int J Syst Evol Microbiol 55, 1301-1304.

Shimomura, K., Kaji, S. \& Hiraishi, A. (2005). Chryseobacterium shigense sp. nov., a yellow-pigmented, aerobic bacterium isolated from a lactic acid beverage. Int J Syst Evol Microbiol 55, 1903-1906.

Tai, C. J., Kuo, H. P., Lee, F. L., Chen, H. K., Yokota, A. \& Lo, C. C. (2006). Chryseobacterium taiwanense sp. nov., isolated from soil in Taiwan. Int J Syst Evol Microbiol 56, 1771-1776.

Vandamme, P., Bernardet, J.-F., Segers, P., Kersters, K. \& Holmes, B. (1994). New perspectives in the classification of the flavobacteria: description of Chryseobacterium gen. nov., Bergeyella gen. nov., and Empedobacter nom. rev. Int J Syst Bacteriol 44, 827-831.

Weon, H. Y., Kim, B. Y., Yoo, S. H., Kwon, S. W., Cho, Y. H., Go, S. J. \& Stackebrandt, E. (2006). Chryseobacterium wanjuense sp. nov., isolated from greenhouse soil in Korea. Int J Syst Evol Microbiol 56, 1501-1504.

Wilson, K. (1987). Preparation of genomic DNA from bacteria. In Current Protocols in Molecular Biology, pp. 2.4.1-2.4.5. Edited by F. M. Ausubel, R. Brent, R. E. Kingston, D. D. Moore, J. G. Seidman, J. A. Smith \& K. Struhl. New York: Green Publishing \& Wiley-Interscience.

Yabuuchi, E., Kaneko, T., Yano, I., Moss, C. W. \& Miyoshi, N. (1983). Sphingobacterium gen. nov., Sphingobacterium spiritivorum comb. nov., Sphingobacterium multivorum comb. nov., Sphingobacterium mizutae sp. nov., and Flavobacterium indologenes sp. nov.: glucose nonfermenting Gram-negative rods in CDC groups IIK-2 and IIb. Int J Syst Bacteriol 33, 580-598.

Yoon, J. H., Kang, S. J. \& Oh, T. K. (2007). Chryseobacterium daeguense sp. nov., isolated from wastewater of a textile dye works. Int J Syst Evol Microbiol 57, 1355-1359.

Young, C. C., Kämpfer, P., Shen, F. T., Lai, W. A. \& Arun, A. B. (2005). Chryseobacterium formosense sp. nov., isolated from the rhizosphere of Lactuca sativa L. (garden lettuce). Int J Syst Evol Microbiol 55, 423-426. 